\title{
Organizational Design of Health Office to Improve the Effectiveness of Public Service in Health Affairs in Barru Regency
}

\author{
Mohamad Thahir Haning \\ Department of Public Administration Science, \\ Hasanuddin University, \\ Makassar, Indonesia \\ thahir.haning@gmail.com
}

\author{
Andi Imam Arundhana \\ Department of Nutrition Science, School of Public Health, \\ Hasanuddin University, \\ Makassar, Indonesia \\ andiimam.arundhana@gmail.com
}

\begin{abstract}
Organizational design is an important issue needed to improve effectiveness of public service organization. This study aimed to explain the strategy of organizational design, shape of structural organization, and positioning of human resource in organization. This study was qualitative study through interview and observation in data collection. A total 15 informants have been selected through purposive sampling method. Technique of data analysis has been conducted in three steps, data reduction, data displaying, and synthesis the conclusion. This study found that organizational design of District Health Office of Barru Regency has accordingly the strategic regulation (vision and mission) of health development. Design of organizational structure is hierarchy contained 5 basic elements of public service organization. The current study resulted that human positioning in the structure has commonly not match with the result of job analysis. In summary, organizational design of District Health Office Barru is in conformity with the current policy. Positioning of human resource should be concerned by the government in terms of increasing the effectiveness of public service organization.
\end{abstract}

Keywords: organizational design; strategy; integrating individua; human positioning; public services

\section{INTRODUCTION}

Act no. 25 year 2009 regarding public services requires that all of the public services have to fulfill the principles of quality in providing the services such as. It will promote the customer satisfaction from the services received. An effective organizational design is necessary to produce properly the size of organization (right sizing) based on the district need [1]. It could support the organization to provide the better quality in public services. In Barru Regency, the design of local government organization based on the new paradigm of government organizational reform has been done. The design of the government organization has to be changed at least four times namely Government Regulation no 84 year 2000, Government Regulation no 8 year 2003, Government Regulation no 41 year 2007, and Government Regulation no 18 year 2016 .

However, after implementation of these government regulations, the Barru Government faced some problems such as the problem of determination of local government agencies which is commonly based on the policy of central government instead of the vision and mission of Barru Regency. In addition, the forming process of local government organization is generally conducted by the team work consisted of government agency officials. It means, in determination of nomenclature, the size, and type of agency, could not be done objectively. Another issue, in case of determination the official to fulfill the existing position, is not based on job and workload analysis. Therefore, the official placement in certain positions generally have not based the need of agencies. One of the agencies provided many public services are District Health Office (DHO). This agency has implemented the Government Regulation number 18 year 2016 in this year (2017). This implementation aimed to create the efficient and effective of government organization in supporting the implementation of local government affairs, especially in the field of health.

The effectiveness of local government organization could be observed by the aspect of district strategic policy, organizational structure, and the re-position of the staff to fulfill the position in organization [2]. Through these strategies, based on the three aspects, DHO is able to result the right size of organization based on district need. The objectives of this study are; 1) to describe organizational design of DHO, 2) to describe the organizational structure of $\mathrm{DHO}$, and 3) to describe the human resource positioning in DHO.

\section{RESEARCH METHOD}

This research was a qualitative research, with the locus of the research locus in District Health Office of Barru Regency. A total 15 Informants have been selected through purposive sampling technique. The informants obtained were 1 head of department, 1 secretary, 3 heads of unit, and 7 heads of section at District Health Office, as well as 1 head of organization unit of Barru government and 2 Senators (DPRD). Data collection method were interview and observation. Data analysis is done in 3 steps, namely data reduction, data display and data verification/ conclusion

\section{RESULT AND DISCUSSION}

The results of this study were analyzed based on the organizational design framework proposed an expert which explains that if want to reach effectiveness of organizational design, 3 aspects should be done. First, the strategy that includes domain, objective and goals. Second, organizing modes that include division of labor, coordination for 
completion of the whole task. Third, the integrating individuals that include selection and training of people, design of reward system [3].

The result of study shows that the design of organization structure of DHO Barru is done by referring to Government Regulation number 18 year 2016 regarding Regional Organization. In addition, it also should be in accordance with the vision and mission of Barru Regency described in the RPJMD 2016-2021. The vision of Barru regency government, namely "The realization of Barru regency which more developed, prosperous, obedient principle, and dignified religious noble". The linkage between vision and the structure of the DHO has generally been in accordance with and elaborated in the organizational structure and description of duties and functions of the Health Office as stipulated in Barru Regent's Regulation No. 57 year 2016 (Table 1).

Table 1. Assessment of informant regarding legal basis of establishment of Barru DHO

\begin{tabular}{|c|l|c|c|}
\hline \multirow{2}{*}{ No. } & \multicolumn{1}{|c|}{ Regulation } & \multicolumn{2}{|c|}{ Assessment } \\
\cline { 3 - 4 } & \multicolumn{2}{|c|}{ Yes } & No \\
\hline 1 & $\begin{array}{l}\text { Government Regulation } \\
\text { No. 18 year 2016 }\end{array}$ & $\sqrt{ }$ & \\
\hline 2 & $\begin{array}{l}\text { Regional strategic policy } \\
\text { (vision and mission) }\end{array}$ & $\sqrt{ }$ & \\
\hline 3 & $\begin{array}{l}\text { Regulation of provincial } \\
\text { government }\end{array}$ & & $\sqrt{ }$ \\
\hline 4 & Local regulation (Perda) & $\sqrt{ }$ & \\
\hline 5 & Leader regulation (Perbub) & $\sqrt{ }$ & \\
\hline
\end{tabular}

The strategy of organizational design, consisting of vision, mission, objectives, and domain of organization, would be a guidance in structural design of government [2]. Organizational designs that are conducted with local strategic policy can result in an effective organization to conduct quality public service affairs [4]. In addition, it can create changes in the system of accountability and organizational culture.

The form of organization of Barru DHO, which has been established based on Barru District Regulation No. 7 years 2016, seems to be a hierarchy that shows the clarity of the division of tasks and coordination relationships between organizational units. The right structure can facilitate the decision-making process and services that can make a service of realism of customers satisfaction in public service [3] [4]. The organizational structure of the Barru DHO meet the five elements of organizational structure, according to the theory by Henry Mintzberg (1993), namely 1) the operating core, 2) the strategic apex, 3) the middle-line, 4) the technostructure, and 5) the supporting staff [5]. The result of the existing structure design of the Health Office is more efficient than the previous DHO structural regulation (Government Regulation number 41 year 2007). The number of positions in the current organizational structure is 15 , previously 21 positions or there is a reduction of 5 structural positions in echelon III and IV (Table 2).

Table 2. Comparison of officer position between Government Regulation No 41 year 2007 vs No 18 year 2016 to Barru

DHO

\begin{tabular}{|c|l|c|c|c|}
\hline No. & \multicolumn{1}{|c|}{ Position } & $\begin{array}{c}\text { GR 41/ } \\
\mathbf{2 0 0 7}\end{array}$ & $\begin{array}{c}\text { GR 18/ } \\
\mathbf{2 0 1 6}\end{array}$ & Note \\
\hline 1 & $\begin{array}{l}\text { Head of department } \\
\text { (echelon IIb) }\end{array}$ & 1 & 1 & 0 \\
\hline 2 & $\begin{array}{l}\text { Secretary (echelon } \\
\text { IIIa) }\end{array}$ & 1 & 1 & 0 \\
\hline 3 & $\begin{array}{l}\text { Head of unit } \\
\text { (echelon IIIb) }\end{array}$ & 4 & 3 & -1 \\
\hline 4 & $\begin{array}{l}\text { Head of section } \\
\text { (echelon IVa) }\end{array}$ & 12 & 9 & -3 \\
\hline 5 & $\begin{array}{l}\text { Head of subsection } \\
\text { (echelon IVa) }\end{array}$ & 3 & 2 & -1 \\
\hline & & $\mathbf{2 3}$ & $\mathbf{1 8}$ & $\mathbf{- 5}$ \\
\hline
\end{tabular}

After the organizational structure is formed, the next step is to place employees in the organizational unit [3]. Placement of staff in the position of the Health Office according to the informant assessment, there is still a gap between the terms of position and the employee who occupies the position in the organizational structure of the District Health Office (Table 3).

Table 3. The assessment of informant regarding the requirements of position vs competencies needed for position in DHO

\begin{tabular}{|c|c|c|c|}
\hline \multirow[b]{2}{*}{ No. } & \multirow[b]{2}{*}{ Position } & \multicolumn{2}{|c|}{ Assesment } \\
\hline & & Appropriate & $\begin{array}{c}\text { Inappropriat } \\
\mathrm{e}\end{array}$ \\
\hline 1 & $\begin{array}{l}\text { Head of department } \\
\text { (echelon IIb) }\end{array}$ & & $\sqrt{ }$ \\
\hline 2 & $\begin{array}{l}\text { Secretary (echelon } \\
\text { IIIa) }\end{array}$ & $\sqrt{ }$ & \\
\hline 3 & $\begin{array}{l}\text { Head of unit } \\
\text { (echelon IIIb) }\end{array}$ & & $\sqrt{ }$ \\
\hline 4 & $\begin{array}{l}\text { Head of section } \\
\text { (echelon IVa) }\end{array}$ & & $\sqrt{ }$ \\
\hline 5 & $\begin{array}{l}\text { Head of subsection } \\
\text { (echelon IVa) }\end{array}$ & $\sqrt{ }$ & \\
\hline
\end{tabular}

The promotion of head department of DHO should be conducted by following the procedure of office auction required in Act number 5 years 2014. For instance, employees must follow the process of auction positions for echelon II, as well as fit and proper test for echelon III and IV. In this relation, the informant stated that the result of the auction of office and fit and proper test only as administrative prerequisites, it can be seen that some 
of the officials who have been promoted, generally do not have the competence corresponding to the position, but because it has proximity to the Local Government Head (Regent).

In addition, in terms of staff placement in the existing structural positions, it has not fully conformed to the competencies required in each of the positions within Barru DHO. In fact, based on the previous study, the placement of employees in accordance with their competence will bring innovation in the work [6]. The result of this study found that two aspects have been achieved by DHO Barru Regency and left one gap (bureaucracy position vs competency). To reduce the gap, the DHO has to give training for the bureaucrats to increase the capability and competency based on their position or even to redesign the structure [7].

\section{CONCLUSION}

This study concluded that organizational design of District Health Office is in conformity with the current regulation (Government Regulation number 18 year 2016). The organizational form of Barru DHO is hierarchy described the authority and coordination relationship amongst working unit within DHO. In terms of staff positioning, there were a big gap between the current competencies of the staff and the requirements. On the other hands, not based on the job analysis result.

\section{REFERENCES}

[1] G.Corkindale. The Importance of Organizational Design and Structure [Internet]. Harvard Business Review. 2011 [cited 2017 Sep 16]. Available from: https://hbr.org/2011/02/the-importance-of-organization

[2] M.Thoha. Leadership in Management, (Kepemimpinan Dalam Manajemen). Jakarta: Raja Grafindo Persada; 1993.

[3] M.Thoha. Civil Service Management in Indonesia (Manajemen Kepegawaian Sipil Di Indonesia). Jakarta: Kencana; 2005.

[4] M.T.Haning. Decentralization of Public Authority at District Level of Pangkep Regency (Desentralisasi Kewenangan Publik di Tingkat Kecamatan Kabupaten Pangkep). JAKPP. 2016;2(Juni).

[5] M.T. Haning. Bureaucracy Reform: The Organizational Design for Supporting Public Services in Indonesia. Page 116. Yogyakarta: Ilmu Giri. 2015.

[6] S.G.D.Pini P. The role of organizational structure and workers' competences in the introduction of exploitative and explorative innovation. Unpublished. 2007;1-35.

[7] A.Sargent and T. McConnell. Practical Approaches to Organization Design. 2008. 